\title{
Pola Penyelesaian Konflik Rekognisi Hak Masyarakat Adat Di Kabupaten Sumbawa
}

\author{
Dianto $^{1}$ \\ Dosen IImu Hukum, Institut IImu Sosial dan Budaya Samawa Rea \\ Email: diantosubiyanto@gmail.com
}

\begin{abstract}
This research for analisis strategic solution of conflik rekognition right of indingius pepole in sumbawa district with empiric method and analitic inductive to deductive with goals that conflik conflik rekognition right of indingius pepole in sumbawa district because, The First, difirence of knowlege abaat regulation distrik number 9 year 2015 about Lembaga adat Tana Samawa who substansi it regulated about kingdom suitable with $18 b$ (1) of constitution, biside that rekognition of indingius people regulated in 18b (2) of constitution. The second, learder of district never verification of extension indingius people suitable regulated of Menteri number 52 year 2014 about guide for rekognition of indingius people. strategic solution of conflik rekognition right of indingius pepole in sumbawa district must same knowlege regulation distrik number 9 year 2015 about Lembaga adat Tana Samawa and learder of district never verification of extension indingius people in sumbawa district.
\end{abstract}

Keywords : Conflic, Rekognisition, Indingius People

\begin{abstract}
Abstrak. . Penelitian ini bertujuan untuk menganalisis pola penyelesaian konflik rekognisi hak masyarakat adat di Kabupaten Sumbawa dengan metode penelitian empiris dan analisis induktif deduktif dengan hasil penelitian bahwa Faktor terjadinya konflik rekognisi hak masyarakat adat di kabupaten sumbawa antara lain Pertama, adanya perbedaan penafsiran tentang Perda Kabupaten Sumbawa Nomor 9 Tahun 2015 Tentang Lembaga Adat Tana Samawa yang substansinya mengatur kesultanan sumbawa sesuai dengan amanat konstitusi pasal 18b (1), sedangkan rekognisi hak masyarakat adat diatur dalam konstitusi pasal 18b (2). Kedua, Kepala Daerah Tidak Melakukan Verifikasi keberdaan masyarakat adat di kabupaten Sumbawa sebagaimana amanat permendagri nomor 52 tahun 2014 Tentang Pedoman Pengakuan dan Perlindungan hak Masyarakat Hukum adat. Dalam penyelesaian konflik rekognisi hak masyarakat adat di kabupaten Sumbawa dengan cara antara lain, Pertama, Penyatuan Pemahaman Perda Kabupaten Sumbawa Nomor 9 Tahun 2015 Tentang Lembaga Adat Tana Samawa dan kedua, kepala Daerah segera melakukan verifikasi keberdaaan Hak masyarakat adat di kabupaten Sumbawa.
\end{abstract}

Kata Kunci : Konflik, Rekognisi, Masyarakat adat

\section{PENDAHULUAN}

Tipologi konflik agraria, kriminalisasi, perampasan, penyingkiran, kekerasan yang dilakukan secara sistematis terutama di kawasan hutan terus meningkat. Di kabupaten sumbawa, berdasarkan data $^{1}$ Aliansi Masyarakat adat Nusantara terdapat tiga kasus agraria yang bervariasi dalam satu komunitas adat. Variasi kasus tersebut, masyarakat adat berhadapan dengan masyarakat adat, masyarakat adat berhadapan dengan pemerintah dan masyararakat adat berhadapan dengan

1Jasardi Gunawan, Makalah disampaikan pada Uji Publik Rancangan Peraturan Daerah Tentang Pengakuan Hak masyarakat adat, "Varian Konflik Agraria Masyarakat adat di Kabupaten Sumbawa" Gedung Wanita Sumbawa, Senin 23 Juni 2017. 
perusahaan. Varian konflik agraria tersebut misalnya konflik yang terjadi antara komunitas adat cek bocek dengan perusahaan raksasa PT Newmount Nusa Tenggara, yang mana wilayah kelola masyarakat adat "bajalit" digusur oleh perusahaan, konflik terjadi juga dengan Pemerintah, Konflik juga dengan masyarakat adat sekitar.

Persoalnya yang terjadi bahwa dalam kasus konflik agraria, dari 1400 kasus sengketa agraria di Pengadilan Sumatera Barat tak satupun pihak masyarakat adat dimenangkan. Sama halnya tanah Hak Ulayat Nagari sekitar 100 ha telah berpindah menjadi tanah Kementerian Kehutanan ${ }^{2}$. Di masyarakat Kalimantan Barat, khususnya di Sambas, hak tanah adat tembawang tidak dapat diklaim masyarakat adat karena letaknya berada dalam posisi hutan lindung ${ }^{3}$. Di kabupaten Sumbawa Barat, gugatan masyarakat adat talonang diputuskan N.O, itupun tetapi hal itu lebih dikarenakan adanya penggantian legal standing dari masyarakat adat menjadi perseorangan. Sumbawa sampai saat ini ada 5 kelompok masyarakat adat yang mengalami konflik agraria dengan variannya masing-masing yaitu komunitas adat pekasa konflik dengan kehutanan, komunitas adat cek bocek konflik dengan kehutanan dan perusahaan Newmount Nusa Tenggara ${ }^{4}$, Komunitas adat Kanar konflik dengan Perhutani, Komunitas adat pusu konflik dengan kehutanan, komunitas adat talonang konflik dengan transmingrasi, komunitas adat Ponto ai padeng berhadapan dengan kehutanan ${ }^{5}$.

Argumentasi hukum konflik agraria hak masyarakat adat di wilayahnya di kawasan hutan karena masyarakat adat di kabupaten sumbawa belum ada peraturan daerah yang mengatur pengakuan dan perlindungan masyarakat adat sebagai perintah Undang-Undang Nomor 41 Tahun 1999 Tentang Kehutanan pasal 67 ayat (2) yang menyatakan bahwa "Pengukuhan keberadaan dan hapusnya masyarakat hukum adat sebagaimana dimaksud ayat (1) ditetapkan dengan peraturan daerah." yang kemudian diperkuat oleh Putusan MK No.35/2012 tentang Hutan Adat yang mensyaratkan penetapan masyarakat adat melalui Peraturan daerah untuk mendapatkan hak-hak masyarakat adat atas hutan. Dengan belum adanya Peraturan Daerah tersebut, pada tahun 2016 masyarakat adat yang diadvokasi oleh Aliansi Masyarakat adat Nusantara kabupaten Sumbawa mendorong terbentuknya peraturan daerah tersebut dan masuk program legislasi daerah dengan inisiatif DPRD pada tahun 2017, namun pada tahun 2017 Rancangan peraturan Daerah ini "ditolak" oleh semua Fraksi DPRD Kabupaten Sumbawa karena sudah ada Peraturan Daerah Kabupaten Sumbawa Nomor 9 Tahun 2015 Tentang Lembaga Adat Tanah Samawa.

Substansi Peraturan Daerah Kabupaten Sumbawa Nomor 9 Tahun 2015 Tentang Lembaga Adat Tanah Samawa mengatur terkait kesultanan sumbawa dengan menggunakan dalil konstitusi pasal $18 \mathrm{~b}$ ayat (1) yang berbunyi "Negara mengakui dan menghormati satuan-satuan pemerintahan daerah yang bersifat khusus atau bersifat istimewa yang diatur dengan undang-undang", bukan tentang masyarakat adat sebagaimana amanat konstitusi pasal $18 \mathrm{~b}$ ayat (2) yang berbunyi "Negara mengakui dan menghormati kesatuan-kesatuan masyarakat hukum adat beserta hak-hak tradisionalnya sepanjang masih hidup dan sesuai dengan perkembangan masyarakat dan prinsip negara kesatuan republik indonesia yang diatur dalam Undang-undang". Situasi ini terus mengundang perdebatan di kalangan masyarakat sumbawa yang juga membuat konflik agraria semakin memanas. Terjadinya penangkapan 3 anggota masyarakat adat bakalewang kanar di wilayah adatnya, pengusiran masyarakat adat Ponto ai padeng dari wilayah adatnya, pemasangan tapal batas kehutanan di samping pemukiman masyarakat adat Pusu.

Mekanisme penguasaan Hutan masyarakat adat di sumbawa terjadi chaos dengan mekanisme penetapan kawasan hutan adat oleh negara. Hutan adat ditentukan oleh masyarakat adat dengan mekanisme self identification, diidentifikasi oleh mereka sendiri sebagaimana dalam hukum adat mereka disebut pan aeng-aeng, me tu tumpan nan baeng, siapa yang menemukan itulah yang miliki. Setelah ditemukan kemudian anggota masyarakat adat menyampaikan terkait kepemilikan tanahnya

\footnotetext{
${ }^{2}$ Lihat Emil Kleden, Kompas, 10 Agustur 2007, dan hasil penelitian Asep Yunan Firdaus 2007 hal 8

${ }^{3}$ Lihat hasil Penelitian Antropologi Budaya tentang Pengembangan SDM di Pusat Pengembangan Perbatasan di Sajingan Besar, diksanakan oleh CLDS FH UII bekerjasama dengan Bappeda, Pemerintah Kabupaten Sambas, Provinsi Kalimantan Barat. 2008.

"Jasardi Gunawan dan Irawansyah "Dinamika Kepemilikan Tanah Masyarakat Adat Cek Bocek Selesek Reen Sury" Kemudi: Jurnal Ilmu Pemerintahan, Vol. 3 No.01 Agustus 2018, hal. 149

${ }^{5}$ Febrian anindita, Laporan Kasus Bidang Advokasi Aliansi Masyarakat adat Pengurus Daerah Sumbawa, Semiloka, Mendorong Pengakuan dan perlindungan Masyarakat adat di kabupaten Sumbawa" Hotel Harapan, 12-13 Desember 2019.
} 
dengan batas-batasnya dalam rapulung atau padering masyarakat adat sekaligus dikukuhkan orang tersebut pemilik sah tanah tersebut. Padering ini dilakukan atas dasar filosofi masyarakat adat di sumbawa ktaket ko nene' kangila boat lenge, takut pada Tuhan, malu berbuat buruk. Pedoman, etika dan cara bermusyawarah adalah filosofi "Adat Barenti ko Syara', Syara' Barenti ko Kitabul-lah" inilah yang dijadikan pegangan guna mendapatkan Krik (anugrah) dan Slamat (keselamatan dan keberkatan). ${ }^{6}$

Mekanisme penetapan kawasan hutan adat oleh negara dengan persyaratan masyarakat adat harus dikukuhkan dengan peraturan Daerah ${ }^{7}$ Tentang pengakuan dan perlindungan masyarakat adat. Di kabupaten Sumbawa, Rancangan Peraturan Daerah tentang Pengakuan Masyarakat adat di tolak oleh DPRD Kabupaten Sumbawa padahal Ranperda ini adalah inisiatif DPRD untuk masuk dalam program legislasi Daerah Tahun 2016.

Di samping itu juga mekanisme penetapan kawasan hutan oleh negara dilakukan dengan mekanisme penunjukkan yang pada akhirnya pengaturan ini diajukan yudicial review ke Mahkamah Konstitusi dengan putusan nomor 46/2011 dengan amar putusan mekanisme penetapan kawasan hutan dengan sistem penetapan dengan melibatkan pihak ketiga. Chaos terjadi ketika mekanisme penetapan kawasan hutan dengan sistem penunjukan, negara dengan sewenang-wenang menunjuk kawasan hutan meskipun wilayah tersebut adalah hutan adat yang merupakan wilayah kelola masyarakat adat.

Secara das sollen pemerintah pusat berkewajiban untuk menyelenggarakan sistem pemerintahan yang mensejahterakan dengan memperjuangkan tercapainya pemenuhan hak-hak konstitusional $^{8}$ dan hak-hak tradisional ${ }^{9}$. Dengan harapan dapat memenuhi kebutuhan dasar masyarakat baik secara materiel maupun secara imateriel Akan tetapi, kewajiban yuridis konstitusional terkait pengakuan dan penghormatan terhadap MHA yang dilakukan oleh pemerintah pusat dan daerah masih menjumpai berbagai kendala. Kebijakan negara terkait pelayanan publik yang belum menyentuh nasib masyarakat hukum adat semakin menujukan bukti keberadaan mereka sebagai kelompok minoritas yang acapkali diperlakukan diskriminatif. Pemenuhan hak-hak konstitusional dan tradisional mereka. realitas timpang antara das sollen dan das sein terkait pengakuan dan penghormatan MHA dan hak-hak tradisional cukup nyata. Di satu pihak, Pasal 18B ayat (2), menyatakan bahwa MHA dan Hak-hak tradisionalnya diakui dan dihormati negara sepanjang masih ada, berkesesuaian dengan kehidupan modern dan tidak bertentangan dengan NKRI dan diatur oleh undang-undang. Suatu norma yang lahir setelah amandemen mustahil dirumuskan tanpa kepentigan politis tertentu. Jaminan konstitusional tersebut terbukti tidak efektif.

\section{METODE PENELITIAN}

Penelitian yang digunakan dalam penelitian ini adalah penelitian empiris yang menganalis apa yang terjadi secara faktual dilapangan (das sein) dengan membandingkan dengan apa yang seharusnya (das sollen) dengan pendekatan Peratuan perundang-undangan, Pendekatan konseptual dan pendekatan kasus yang ruang lingkup penelitiannya berlokasi di kabupaten sumbawa dengan tekhnik pengumpulan data wawancara dan studi pustaka dengan analisis data menggunakan induktif deduktif.

${ }^{6}$ Lahmuddin zuhri, Tata Kelola Tanah Lar di Kabupaten Sumbawa jurnal notariil, vol. 2, no. 2, november 2017, 160

7 Pengakuan dan Perlindungan Masyarakat adat dapat juga dilakukan dengan keputusan Kepala Daerah berdasarkan peraturan Menteri Dalam Negeri Nomor 52 Tahun 2014 Tentang Pengakuan dan Perlindungan Masyarakat adat. Bandingkan dengan jasardi gunawan, Jurnal IUS Volume 6 No. 1 tahun 2018, Implementasi Permendagri No. 52 Tahun 2014 Tentang Mekanisme Pengakuan dan Perlindungan Masyarakat hukum adat. Hal. 107

${ }^{8}$ Hak-hak Konstitusional adalah Hak-hak dasar dan Hak kebebasan dasar setiap wargamnegara, terkait dengan pendidikan, pekerjaan, kesetaraan didepan hukum, hak sosial ekonomi, kebebasan berpendapat, hak untuk hidup dan bertempat tinggal yang dijamin oleh UUD

${ }^{9}$ Hak-hak Tradisional yaitu Hak-hak khusus atau istimewa yang melekat dan dimiliki oleh suatu komunitas masyarakat atas adanya kesamaan asal-usul (geneologis), kesamaan wilayah, dan obyek-obyek adat lainnya, hak atas tanah ulayat, sungai, hutan dan dipraktekan dalam masyarakatnya. 


\section{HASIL DAN PEMBAHASAN}

Rekognisi atau pengakuan tidak mengubah norma yang hidup di masyarakat, melainkan hanya menghormati dan melindungi norma yang sudah ada pada komunitas dan wilayah asalnya sesuai dengan asal usulnya. ${ }^{10}$

Rekognisi pada dasarnya juga mengubah tradisi menjadi hukum posistif dengan cara memberlakukannya melalui norma hukum positif. Dalam kaitan dengan UUD 1945, rekognisi dilakukan terhadap satuan-satuan pemerintah yang bersifat khusus atau istimewa, seperti pengakuan terhadap keistimewaan Pemerintah Yogyakarta dan Aceh, serta pengakuan terhadap kesatuan-kesatuan masyarakat adat seperti terhadap sistem pemerintah desa di Jawa, nagari di Minangkabau, atau banjar di Bali (Pasal 18B UUD 1945). ${ }^{11}$

Menurut Honneth Dalam Rian Adhivira Prabowo ${ }^{12}$, rekognisi adalah laku kognitif secara sadar akan ancaman dari yang lain sehingga mampu mengenali yang lain sebagai bagian darinya secara total, sebagaimana dikatakan oleh Honneth:

In this new context, 'recognition' refers to the cognitive step taken by a consciousness that has already developed 'ideally' into a totality, at the moment in which it 'perceives itself in another such totality, consciousness - to be the totality it is. And the reason why this experience of perceiving oneself in others has to lead to a conflict or struggle is that it is only by mutually violating each other's subjective claims that individuals can come to know whether or not, in them, the respective others also re-identify themselves as a 'totality'...

Teori Charles Taylor mengenai politik rekognisi yang secara filosofis diinspirasi oleh Hegel dan Honneth. Pada mulanya, politik rekognisi berangkat dari kajian filsafat, budaya dan politik identitas. Kajian filsafat yang menonjol mengenai rekognisi diajukan oleh Hegel ${ }^{13}$. Pentingnya penerapan politik pengakuan (politics of recognition) yang dapat menjadi landasan bagi terciptanya kebersamaan di antara berbagai budaya, kelompok etnis, ras dan agama. Sebab tak adanya pengakuan adalah penindasan (misrecognition is an oppression)(Anderson ${ }^{14}$

Dalam perspektif ini, pengakuan bukan hanya sekedar suatu kebaikan yang berlaku dalam diri. Pengakuan adalah kebutuhan vital manusia. Kesalahan pengakuan dapat menunjukkan adanya kesenjangan yang dapat menyebabkan luka yang mendalam, membebani korbannya dengan tekanan batin yang menyiksa. Menambahkan gagasan Taylor, Andersson menyatakan bahwa hakikat politik rekognisi pada perkembangannya adalah politik rekognisi etnik. ${ }^{15}$

Di samping teori rekognisi untuk analisis konflik rekognisi hak masyarakat adat juga menggunakan teori mazhab sejarah. Mazhab sejarah dari Carl von Savigny (Volksgeist) merupakan antitesis dari mazhab positifistik, dalam ajaran positifistik sumber hukum merupakan norma hasil kesepakatan dari pemegang kekuasaan, diluar itu tidak dianggap sebagai hukum, sementara Von Savigny menyatakan hukum kebiasaan atau hukum adat-lah yang merupakan sumber hukum formal. Hukum tidak dibuat melainkan tumbuh dan berkembang bersama-sama dengan masyarakat.

Theo Hujaiber menyatakan:

"Menurut F. von Savigny hukum merupakan salah satu faktor dalam kehidupan bersama suatu bangsa, seperti bahasa, adat, moral, tatanegara. Oleh karena itu hukum adalah sesuatu yang bersidat supra-indiidual, suatu gejala masyarakat. Tetapi suatu masyarakat lahir dalam sejarah. Nyatalah hukum yang termasuk masyarakat itu serta dalam perkembangan organis itu. Lepas dari masyarakat tidak terdapat hukum sam sekali". ${ }^{16}$

${ }^{10}$ Aidul Fitriciada Azhari. Rekontruksi Tradisi Bernegara Dalam UUD 1945. Yogyakarta: Genta Publishing. 2014. Hal. 16

${ }^{11}$ Ibid aidul

12 Rian Adhivira Prabowo, Politik Rekognisi Axel Honneth: Relevansinya terhadap Jaminan Kesetaraan dalam Hukum di Indonesia. Jurnal IImu Pemerintahan, Vol. 4, No. 2, 2019, 75-88. Hal. 77

${ }^{13}$ Douzinas, C. 2002. "Identity, Recognition, Rights or What Can Hegel Teach Us About Human Rights?".Journal of Law and Society. Vol 29 No 3, hlm. 380

${ }^{14}$ Lovell, T (ed.). 2007. (Mis)recognition, Social Inequality and Social Justice: Nancy Fraser and Pierre Bourdieu. London and New York: Routledge. 2009: 37-45; Lovell, 2007: 2-3).

15 (bid, 2-3).

${ }^{16} \mathrm{Ibid}$. Hal 10 
Von Savigny menegaskan inti ajarannya, bahwa hukum itu tidak di buat, tetapi tumbuh dan berkembang bersama masyarakat. Pandangannya bertitik bahwa di dunia ini terdapat banyak bangsa, dan tiap-tiap bangsa memiliki suatu 'volksgeist' jiwa rakyat. Jiwa ini berbeda, baik menurut waktu maupun tempat, pencerminannya nampak pada kebudayaan masingmasing yang berbedabeda, hukum yang bersumber dari jiwa rakyat ini, oleh karena itu hukum itu akan berbeda pada setiap tempat dan waktu, tidaklah masuk akal terdapat hukum yang universal dan abadi. Selanjutnya Von Savigny menyatakan bahwa apa yang menjadi isi hukum itu di tentukan oleh pergaulan hidup manusia dari masa-kemasa, hukum berkembang dari suatu masyarakat sederhana yang tercermin pada setiap tingkah laku individuindividu kepada suatu masyarakat yang kompleks dimana kesadaran hukum masyarakat nampak pada ucapan-ucapan para ahli hukumnya. Jiwa ini contoh hukum kebiasaan Germania yang beraneka ragam. Ajaran Von Savigny di kembangkan oleh G. Pactha, Van Volenhoveen dan Ter Har, pengaruhnya pada hukum adat Indonesia sangat kuat, tokoh mazhab sejarah lainnya ialah Sir Henry Maine. Muhtar kusumaatmaja sebagaimana di kutip Mahfu MD menyatakan, Pada era 1970-an dimana pembentukan hukum dilakukan lewat GBHN Mazhab sejarah dan dan postivistik sempat mewarnai perdebatan pembentukan hukum Indonesia. Aliran legisme (hukum positif) menghendaki pembuatan hukum adat dilakukan dengan undang-undang, sementara mazhab sejarah menatang penyamaan hukum dengan undang-undang, sebab hukum itu tidak mungkin di buat, melainkan tumbuh dari kesadaran hukum masyarakat. ${ }^{17}$

Teori hukum yang di kemukakan Savigny sangat relevan untuk mengoptik masalah yang di angkat dalam judul penulisan ini, yakni Politik Hukum Adat Bima: Dari Sintesis, Transplantasi Hingga Konservasi Hukum. Relevansi teori hukum sejarah yang dikembangkan Savigny sangat tepat mengkostruksi tranpslantasi hukum modern yang menurut Henry Marryman ada tiga besar rumpun keluarga hukum di era mdern ini, yakni; 'civil law sistym,' 'common law sistym,' dan 'social law sistym,' ketiga sistem hukum tersebut memiliki basis asal dan penyebarannya masing-masing, namun dari ketiga sistem hukum tersebut, yang paling agresif, melakukan pencakokan (tranplantasi) dan yang banyak diadopsi negara lain baik melalui penaklukan secara sukarela (voluntary) maupun secara paksa atau penjajahan (force) adalah keluarga rumpun sistem hukum 'Civil Law' yang dikembangkan oleh Jerman dan Perancis, dan Indonesia mengikuti dua model tersebut dan lebih khusus Perancis melalui koloni Belanda, 'common law system' juga sangat berkembang dan diadopsi oleh banyak negara. Kedua sistim hukum ini bersumber dari hukum Romawi kono dan ajaran Kristiani yang dibukukan oleh Napoleon Bonaparte (code napoleon).

\section{A. Faktor-Faktor Terjadinya Konflik Rekognisi Hak Masyarakat Adat di Kabupaten Sumbawa}

1. Adanya Perbedaan penafsiran Peraturan Daerah Nomor 9 Tahun 2018 Tentang Lembaga Adat Tana Samawa

Regulasi yang mengatur secara khusus rekognisi hak masyarakat adat di sumbawa belum ada. Ranperda tentang rekognisi ini pernah menjadi inisiatif DPRD kabupaten Sumbawa menjadi bagian program legislasi Daerah pada tahun 2016 dan dibahas pada tahun 2017. Namun pada saat pembahasan ranperda ini ditolak ${ }^{18}$ oleh semua Komisi dan Fraksi di DPRD Kabupaten sumbawa dengan berbagai macam alasan antara lain telah Lahirnya peraturan Daerah Kabupaten Sumbawa Nomor 9 Tahun 2015 Tentang lembaga adat Tana Samawa.

Berdasarkan hasil Penelitian Mulyanto ${ }^{19}$ dalam disertasinya untuk menganalisis penataan kesatuan masyarakat hukum adat menjadi desa adat, khususnya di Provinsi Bali dari perspektif politik hukum," Meski memberi harapan, kata Mulyanto, Undang-Undang 2003, hlm. 59

${ }^{17}$ Mahfud MD, Politik Hukum Menuju Pembangunan Sistem Hukum Nasional, Majalah Hukum Nasional-BPHN, Nomor. 2 Tahun

${ }^{18}$ Pulausumbawanews.net Seluruh Fraksi Dewan Tolak Ranperda Masyarakat adat diakses pada tanggal 26 Januari 2020

${ }^{19}$ Mulyanto, Intisari Disertasinya tentang penataan kesatuan masyarakat hukum adat menjadi desa adat, khususnya di Provinsi Bali dari perspektif politik hukum," yang diteliti oleh pada tahun 2018 dari Program Doktor Ilmu hukum Universitas Gajah Mada 
No.6 Tahun 2014 memiliki kelemahan. Berdasarkan hasil kajian konstruksi politik hukum, UU No.6 Tahun 2014 dinilai mengandung kelemahan konseptual, yakni harus memilih salah satu jenis desa dengan model integrasi (integrated village).

Sementara realitas sosial kehidupan masyarakat Bali lebih menghendaki model koeksistensi (co-existence) tanpa harus menegasikan salah satu desa. Sebab, Desa Adat (Pakraman) dan Desa Dinas dapat hidup berdampingan, saling melengkapi ibarat pasangan suami-istri yang berjalan harmonis.

Untuk itu, menurut Mulyanto, perlu dilakukan perubahan mendasar terhadap politik hukum penataan kesatuan masyarakat hukum adat menjadi desa adat. Dengan mengganti model integrasi (integrated village) menjadi model koeksistensi (co-existence) nantinya Desa dan Desa Adat dapat hidup berdampingan berdasarkan fungsi masing-masing dengan saling melengkapi sesuai amanat Pembukaan UUD 1945.

\section{Tidak dilakukan verifikasi terhadap keberadaan masyarakat adat di kabupaten Sumbawa}

Dalam peraturan Menteri dalam Negeri nomor 52 Tahun 2014 Tentang Pedoman Pengakuan dan Perlindungan masyarakat adat mengatur kewenangan kepala Daerah menetapkan pengakuan dan perlindungan masyarakat adat dengan melakukan verifikasi terlebih dahulu terhadap keberadaan masyarakat adat. Kewenangan verifikasi ini tidak digunakan oleh pemerintah daerah yang dalam hal ini bupati sumbawa sehingga upaya rekognisi hak masyarakat sulit dilakukan sementara masyarakat adat menuntut pengakuan kepada pemerintah daerah.

Dalam penelitian Jasardi Gunawan tentang implementasi Permendagri No. 52 Tahun 2014 Tentang Pedoman Pengakuan dan Perlindungan Masyarakat Hukum Adat, di Kabupaten Sumbawa menyimpulkan bahwa Impelementasi Permendagri No 52 Tahun 2014 Tentang Pedoman Pengakuan dan Perlindungan Masyarakat Hukum Adat di Kabupaten Sumbawa, sampai saat ini belum dapat dilaksanakan oleh Kepala Daerah Kabupaten Sumbawa. Sehingga keberadaan masyarakat hukum adat Cek Bocek Selesek Reen Suri belum memeliki legal standing atau posisi hukum yang jelas. Karena Bupati Sumbawa tidak melaksanakan Permendagri tersebut. ${ }^{20}$

\section{B. Pola Penyelesaian Konflik Rekognisi Hak Masyarakat adat Di kabupaten Sumbawa}

1. Penyatuan penafsiran terkait Peraturan Daerah Kabupaten Sumbawa Nomor $\mathbf{9}$ Tahun 2015 Tentang Lembaga Adat Tanah Samawa

Substansi Peraturan Daerah Kabupaten Sumbawa Nomor 9 Tahun 2015 Tentang Lembaga Adat Tanah Samawa mengatur terkait kesultanan sumbawa dengan menggunakan dalil konstitusi pasal $18 \mathrm{~b}$ ayat (1) yang berbunyi "Negara mengakui dan menghormati satuan-satuan pemerintahan daerah yang bersifat khusus atau bersifat istimewa yang diatur dengan undang-undang", bukan tentang masyarakat adat sebagaimana amanat konstitusi pasal $18 \mathrm{~b}$ ayat (2) yang berbunyi "Negara mengakui dan menghormati kesatuan-kesatuan masyarakat hukum adat beserta hak-hak tradisionalnya sepanjang masih hidup dan sesuai dengan perkembangan masyarakat dan prinsip negara kesatuan republik indonesia yang diatur dalam Undang-undang". Situasi ini terus mengundang perdebatan di kalangan masyarakat sumbawa yang juga membuat konflik agraria terus terjadi.

${ }^{20}$ Jasardi Gunawan, implementasi Permendagri No. 52 Tahun 2014 Tentang Pedoman Pengakuan dan Perlindungan Masyarakat Hukum Adat, di Kabupaten Sumbawa Jurnal IUS Vol. VI Nomor 1 April 2018 , Hal. 179 


\section{Kepala Daerah Melakukan Verifikasi keberdaan Masyarakat adat di kabupaten Sumbawa}

Dalam rangka penyelesaian konflik rekognisi hak masyarakat adat maka pemeritah Daerah perlu melakukan verifikasi keberdaan masyarakat adat di kabupaten Sumbawa karena ini perintah Permendagri No 52 Tahun 2014 Tentang Pedoman Pengakuan dan Perlindungan Masyarakat Hukum Adat dengan menetapkan tim verifikasi untuk melakukan verifikasi keberadaan masyarakat adat di sumbawa. Dalam simpulan penelitian yang dilakukan oleh M. Syukron anshori ${ }^{21}$ dkk menyatakan bawhwa Konflik urusan pertanahan yang melibatkan perangkat daerah pada masyarakat adat Cek Bocek Salesek Reen Sury dan PT. Newmont Nusa Tenggara di Kabupaten Sumbawa selama ini tidak mengarah pada conflict resolution. Konsep pola komunikasi intermediaries diharapkan mampu mengurai persoalan-persoalan konflik melalui negosiasi dengan keterlibatan pihak ketiga.

\section{KESIMPULAN}

Faktor terjadinya konflik rekognisi hak masyarakat adat di kabupaten sumbawa antara lain Pertama, adanya perbedaan penafsiran tentang Perda Kabupaten Sumbawa Nomor 9 Tahun 2015 Tentang Lembaga Adat Tana Samawa yang substansinya mengatur kesultanan sumbawa sesuai dengan amanat konstitusi pasal 18b (1), sedangkan rekognisi hak masyarakat adat diatur dalam konstitusi pasal 18b (2). Kedua, Kepala Daerah Tidak Melakukan Verifikasi keberdaan masyarakat adat di kabupaten Sumbawa sebagaimana amanat permendagri nomor 52 tahun 2014 Tentang Pedoman Pengakuan dan Perlindungan hak Masyarakat Hukum adat. Dalam penyelesaian konflik rekognisi hak masyarakat adat di kabupaten Sumbawa dengan cara antara lain, Pertama, Penyatuan Pemahaman Perda Kabupaten Sumbawa Nomor 9 Tahun 2015 Tentang Lembaga Adat Tana Samawa dan kedua, kepala Daerah segera melakukan verifikasi keberdaaan Hak masyarakat adat di kabupaten Sumbawa.

\section{DAFTAR PUSTAKA}

Azhari, Aidul Fitriciada. (2014) Rekontruksi Tradisi Bernegara Dalam UUD 1945. Yogyakarta: Genta Publishing..

Anindita, Febrian, (2019) Laporan Kasus Bidang Advokasi Aliansi Masyarakat adat Pengurus Daerah Sumbawa, Semiloka, Mendorong Pengakuan dan perlindungan Masyarakat adat di kabupaten Sumbawa" Hotel Harapan, 12-13 Desember 2019.

Ashori, M. Syukron dkk, (2017) Negotiation Intermediaries dan identifikasi Penyelesaian Sengketa Hak atas tanah Masyarakat Adat Cek Bocek Salesek Reen Sury Di Kabupaten Sumbawa, Jurnal IUS, Vol. V Nomor 3,

Douzinas, C. ( 2002.) "Identity, Recognition, Rights or What Can Hegel Teach Us About Human Rights?".Journal of Law and Society. Vol 29 No 3.

Lovell, T (ed.).( 2007). (Mis)recognition, Social Inequality and Social Justice: Nancy Fraser and Pierre Bourdieu. London and New York: Routledge. 2009: 37-45; Lovell,

Mahfud MD, (2003) Politik Hukum Menuju Pembangunan Sistem Hukum Nasional, Majalah Hukum Nasional-BPHN, Nomor. 2 .

Gunawan, Jasardi dan Irawansyah, (2018) "Dinamika Kepemilikan Tanah Masyarakat Adat Cek Bocek Selesek Reen Sury" Kemudi: Jurnal Ilmu Pemerintahan, Vol. 3 No.01

Gunawan, Jasardi, (2017) Makalah disampaikan pada Uji Publik Rancangan Peraturan Daerah Tentang Pengakuan Hak masyarakat adat, "Varian Konflik Agraria Masyarakat adat di Kabupaten Sumbawa" Gedung Wanita Sumbawa, Senin 23 Juni 2017.

${ }^{21}$ M. Syukron Ashori dkk, Negotiation Intermediaries dan identifikasi Penyelesaian Sengketa Hak atas tanah Masyarakat Adat Cek Bocek Salesek Reen Sury Di Kabupaten Sumbawa, Jurnal IUS, Vol. V Nomor 3 hal . 149 
Gunawan, jasardi, (2018), Implementasi Permendagri No. 52 Tahun 2014 Tentang Mekanisme Pengakuan dan Perlindungan Masyarakat hukum adat. Jurnal IUS Volume 6 No. 1

Prabowo, Rian Adhivira, (2019,) Politik Rekognisi Axel Honneth: Relevansinya terhadap Jaminan Kesetaraan dalam Hukum di Indonesia. Jurnal IImu Pemerintahan, Vol. 4, No. 2,

Zuhri , Lahmuddin, (2017) Tata Kelola Tanah Lar di Kabupaten Sumbawa jurnal notariil, vol. 2, no. 2 